DOI: https://doi.org/10.32836/2521-666X/2019-65-32

УДК 338.24.01:336.025

\author{
Tiutiunyk Inna \\ Sumy State University \\ Тютюник I. B. \\ кандидат економічних наук, доцент, \\ Сумський державний університет
}

\title{
ANALYTICAL ASSESSMENT OF TAX GAPS DEPENDING ON THE LEVEL OF THE SHADOW ECONOMY
}

\section{АНАЛІТИЧНА ОЦІНКА СКЛАДОВИХ ЕЛЕМЕНТІВ ПОДАТКОВИХ РОЗРИВІВ ЗАЛЕЖНО ВІД РІВНЯ ТІНІЗАЦІЇ ЕКОНОМІКИ}

One of the most threatening consequences of the existence of a shadow economy is the formation of tax gaps that reduce the effectiveness and speed of economic and social reforms in the country and reduce the level of its macroeconomic stability. The article analyses theoretical approaches to the identification of the main determinants of tax gaps in the economy. The influence of the shadow economy on the volume of tax breaks is substantiated. Based on empirical estimates, the hypothesis of a linear, nonlinear, and asymmetric relationship between drivers of tax gap formation and the level of shadowing of the economy is tested. The existence of nonlinear communication for countries with a level of shadow economy more than $40 \%$, a linear relationship between the analysed indicators and a level of shadowing less than $20 \%$ and asymmetric for the share of the informal economy of $20-40 \%$ is proved.

Key words: tax gap, economy development, tax evasion, shadow economy, tax payments.

Одним із найбільш загрозливих наслідків існування тіньового сектору економіки є формування податкових розривів. Саме невідповідність фактичних податкових надходжень держави їі потениійним можливостям суттєво знижує ефективність та швидкість проведення економічних та соиіальних реформ в країні та скорочує рівень ії макроекономічної стабільності. У статті аналізуються теоретичні підходи до ідентифікаиії основних детермінант виникнення податкових розривів в економічі. В роботі емпірично досліджено прямі та зворотні зв 'язки між економічними, соціальними та інституційними показниками розвитку краӥн та обсягом податкових розривів. Обтрунтовано вплив тіньових економічних прочесів країні на обсяг податкових розривів. На основі емпіричних оцінок в роботі перевірено гіпотези про наявність лінійного, нелінійного та асиметричного зв'язку між драйверами формування податкових розривів та рівнем тінізації економіки. Аналіз ступеня впливу факторних ознак на результуючий показник здійснювався в розрізі наступних груп краӥн: країни, з рівнем тінізації менше 20\%, 20-30\%, 30-40\%, 40-50\% та більше 50\%. Систематизачія літературних джерел та аналіз основних проблем економічного розвитку краӥни дозволили виокремити найбільш вагомі драйвери впливу на податкові розриви в економіці, до яких віднесено: кількість податкових платежів, рівень податкового навантаження, рівень безробіття, заробітної плати, обсяг державного боргу, ВВП, рівень корупиії, інфлячії, обсяги прямих іноземних інвестицій, експорту та імпорту. Доведено наявність нелінійного зв'язку для країн з рівнем тінізації економіки більше 40\%, лінійної залежності між аналізованими показниками за рівня тінізачї менше 20\% та асиметричного при часті неофіџійної економіки 20-40\%. Зроблено висновок про те, однією з причин низької ефективності впровадження інструментарію державного регулювання, зокрема в сфері податкового регулювання, є недостатнє врахування наслідків стрімкого зростання обсягів тіньових операцій в процесі планування державної політики щодо забезпечення ключових напрямів економічного розвитку країни. Встановлені взаємозалежності можуть забезпечити формування кращсого розуміння найбільш впливових факторів ухилення від оподаткування.

Ключові слова: податковий розрив, економічний розвиток, ухилення від сплати податків, тінізація економіки, податкові платежі. 
Одним из наиболее угрожающих последствий существования теневого сектора экономики является формирование налоговых разрывов, которые снижают эффективность и скорость проведения экономических и соииальных реформ в стране и сокращают уровень ее макроэкономической стабильности. В статье анализируются теоретические подходы к идентификации основных детерминант возникновения налоговых разрывов в экономике. Обосновано влияние теневых экономических прочессов на объем налоговых разрывов. На основе эмпирических оценок в работе проверено гипотезы о наличии линейной, нелинейной и асимметричной связи между драйверами формирования налоговых разрывов и уровнем тенизации экономики. Доказано наличие нелинейной связи для стран с уровнем тенизации экономики более 40\%, линейной зависимости между рассматриваемыми показателями при уровне тенизации менее $20 \%$ и асимметричной при доле неофициальной экономики 20-40\%.

Ключевые слова: налоговый разрыв, экономическое развитие, уклонение от уплаты налогов, тенизация экономики, налоговые платежи.

Formulation of the problem. In recent years, tax evasion is actively investigated by representatives of the international economic community of the vast majority of countries in the world. However, unfortunately, the available theoretical and empirical studies did not give an unambiguous answer to this problem.

One of the reasons for this situation is the fact that tax gaps in the economy appear due to not only objective (legally defined privileges and tax exemptions for certain types of activity or taxpayers) but also subjective (deliberate illegal actions of taxpayers to avoid fulfilment of their obligations) reasons, preconditions for which include the deterioration of country's economic and social development indicators, the aggravation of the political crisis, etc. Most of the scientific works related to the study of tax evasion determinants, the assessment of the relationship between the general indicators of the shadow economy, and the number of tax gaps. However, there are practically no detailed studies of the impact, made by certain economic development factors, on the volume of tax gaps.

In addition, it is the value of tax remissions, surcharges and benefits provided by the government to compensate for the source of income that might otherwise be taxed.

The most studied in terms of the tax gap assessment is VAT, which varies substantially between countries, ranging from $1.4 \%$ (for Sweden) and $37.18 \%$ (for Romania). According to estimates by international experts, the total loss in the EU is estimated at 151.5 billion EUR [10].

Analysis of recent research and publications. However, in the context of countering the economic shadowing, a greater amount of research has become a tax compliance gap. Scientists are exploring the tools, reasons, and motives for deliberately concealing their income and practically do not pay attention to tax policy gap. Thus, the governments of the overwhelming majority of the world virtually ignore the possibility of tax revenues growth by reviewing the expediency of tax privileges and their optimization.

All determinants of tax gaps can be divided into four groups: economic, industrial specialization or structural, social, and institutional. Economic factors include GDP per capita, the volume of exports and imports of goods and services in a percentage of GDP, and the volume of direct foreign investment in fixed capital. Factors of production specialization include two variables: the added value formed in agriculture as a percentage of GDP and the value-added of industry ( $\%$ of GDP). Social factors consist of three variables: the total number of higher education institutions, life expectancy, and infant mortality rates. Institutional factors consist of two indicators that essentially measure the level of democracy and the level of civil liberty (freedom of expression, legal security)

Riahi-Belkaoui divided all approaches to justifying tax evasion determinants into three types: the theory of general deterrence, the model of economic restraint and fiscal psychological models [8].

The models of economic containment are based on the comparison between volumes of costs and benefits for taxpayers who evade taxation. According to this model, a person will be inclined to avoid taxation until the benefits outweigh the expected costs (fines or other 
payments) related to the detection of the tax laws violation $[4 ; 3]$. The economic, legal, and institutional peculiarities of the country (quality of the legal system, the level of corruption, bureaucracy, state regulation of competition) are factors, which determine the payer's predilection to the illegal withdrawal of funds.

Fiscal psychological models study the tax payers' convictions and predict their behaviour to comply with tax laws. These models include the study of tax history and the identification of the reasons that led them to avoid taxation [6]. According to these models, the most influential factors are age, gender, the payer's social and economic status, the level of education and profession, the level of tax morality.

Proponents of the general deterrence theory confirm that the level of financial crime decreases under the influence of the threat of punishment. The factors driving the growth of taxpayer's liability are the awareness of the consequences, speed, the severity of punishment for violating the law [9].

Akinboade concluded that the economic sector has a significant impact on the level of the tax gap. Thus, representatives of the manufacturing sector are more inclined to tax evasion, even if the production sphere is not a determining factor in the complexity of the business registration processes and the further business run. The age and sex of the business owner, the degree of awareness about the specifics of the small and medium enterprises' work do not affect the level of compliance with tax legislation. The author emphasizes that the higher the level of owner's education, the higher the probability of compliance with the law [1].

Annan took a model of the demand for the currency as a basis to define tax evasion determinants in Ghana from 1970 to 2010. Using Auto-Regressive Distributed Lag, he concluded that per capita income, average tax rate, age, and inflation are positively and significantly related to tax evasion while gender differences have a negative and significant relationship with tax evasion [2].

In Murphy's point of view, tax evasion includes the following determinants: trading in shadow economy, untaxed proceeds of frauds and other crime, capital gains tax, inheritance tax, offshore tax abuse, criminal attacks on the tax system, failure to take care (taxpayers' errors or negligence), error (resulting from the action) [7].

Langford and Ohlenburg evaluate the completeness of the tax revenues and the level of the tax potential, based on the data of the 27-year period for 85 countries, which are characterized by the average and low level of development. Authors use the industry structure, education and trade as impact factors. The authors include the Corruption Perceptions Index, the ratio of the shadow economy to GDP, and the level of the economic openness to the exogenous variables that influence the inefficiency of VAT revenues [5].

The purpose of the article is to identify the drivers of the tax gaps formation in the economy, to determine the nature and direction of their impact on the resulting indicator.

Presenting the main material. The main hypothesis of the work is the existence of a close connection between the main drivers of the shadow economy, to which we refer: a number of tax payments, level of tax burden, level of unemployment, salary, public debt, GDP, level of corruption, inflation, volume of foreign direct investments, exports and imports.

The stable correlation between the defined indicators is confirmed in terms of the countries by the level of shadowing of the economy. However, it should be noted that for countries in which a size of shadowing is less than $20 \%$, the stability of the established communications is reduced and for a number of factorial features is absent at all. For example, the linear relationship between the tax gap and the level of unemployment, the volume of public debt, the level of inflation and the rate of population growth for countries with a level of shadowing of less than $20 \%$ was not confirmed. These results determine the need to verify the nonlinear relationship between the analysed indicators (Table 1).

Similar dependencies between indicators have been obtained as a result of the analysis by the group of countries according to the level of shadowing of the economy. Almost all 
Table 1

Results of the hypothesis verification regarding the linear relationship between drivers and tax gaps in terms of countries by the level of shadowing of the economy

\begin{tabular}{|c|c|c|c|c|c|c|}
\hline Drivers & All countries & $\mathbf{> 5 0 \%}$ & $\mathbf{4 0 - 5 0 \%}$ & $\mathbf{3 0 - 4 0 \%}$ & $\mathbf{2 0 - 3 0 \%}$ & $<\mathbf{2 0 \%}$ \\
\hline TP & 0.1781 & 0.1700 & 0.1709 & 0.1674 & 0.1875 & 0.1864 \\
\hline TBB & 0.3250 & 0.1917 & 0.1873 & 0.1829 & 0.4147 & 0.4243 \\
\hline UNE & $0.1376^{*}$ & $0.0817^{*}$ & $0.1890^{*}$ & $0.1978^{*}$ & $0.0730^{*}$ & 0.0638 \\
\hline RAS & $-0.2764^{*}$ & $-0.1612^{*}$ & $-0.1305^{*}$ & $-0.0306^{*}$ & $-0.2948^{*}$ & $-0.5152^{*}$ \\
\hline PD & $0.0198^{*}$ & $0.1357^{*}$ & $0.2562^{*}$ & $0.1381^{*}$ & $0.1542^{*}$ & 0.1852 \\
\hline GPD & $-0.1868^{*}$ & $-0.0066^{*}$ & -0.0965 & -0.0472 & $-0.0891^{*}$ & $-0.0231^{*}$ \\
\hline COR & $0.1962^{*}$ & $0.1738^{*}$ & $0.0575^{*}$ & $0.0721^{*}$ & $0.1937^{*}$ & 0.1738 \\
\hline INF & $0.0602^{*}$ & $0.1492^{*}$ & $0.0259^{*}$ & $0.1128^{*}$ & $0.1310^{*}$ & 0.1581 \\
\hline FDI & -0.0019 & -0.0012 & -0.0015 & -0.0015 & -0.0024 & -0.0020 \\
\hline EXP & -0.0611 & -0.0345 & -0.0469 & -0.0458 & -0.0936 & -0.0689 \\
\hline IMP & -0.0010 & -0.0010 & -0.0017 & -0.0016 & -0.0020 & -0.0012 \\
\hline
\end{tabular}

dependencies in Table 2 confirm a statistically significant correlation relationship. At the same time, for countries with the shadow economy levels of $40 \%$ or more and from $20 \%$ to $30 \%$, the nonlinear relationship between the resulting indicator and the imports volume is not statistically significant. In our opinion, the reasons for this situation may include the necessity for a deeper study of the relationship between indicators using a wider list of models and methods; the unreliability of the used data. It is quite often that data regarding the level and the amount of the economy shadowing is inaccurate due to the lack of an integrated approach to determining and fully taking into account potential channels for a decrease of their tax payments, deliberate underestimation of the illegal operations volumes by countries' governments (Table 3 ).

Conclusions. Tax revenues form an important part of the revenue share of the country's budget. The tendencies regarding the development of the world economy in recent years prove the shadow sector growth, one of the consequences of which includes the tax gaps formation in the economy.

However, the absence of an integrated and unified methodology to study the level of tax gaps in the economy does not let make general and valid conclusions. In our work, we have proved that the analysed factors influence the number of tax gaps in some countries in a different way. The reasons for these differences in the

Table 2

Results of the hypothesis verification regarding the nonlinear relationship between drivers and tax gaps in the context of countries with different level of shadowing of the economy

\begin{tabular}{|c|c|c|c|c|c|c|}
\hline Drivers & All countries & $\mathbf{> 5 0 \%}$ & $\mathbf{4 0 - 5 0 \%}$ & $\mathbf{3 0 - 4 0 \%}$ & $\mathbf{2 0 - 3 0 \%}$ & $<\mathbf{2 0 \%}$ \\
\hline TP & $0.1799^{*}$ & $0.1605^{*}$ & $0.1960^{*}$ & $0.1729^{*}$ & $0.2717^{*}$ & $0.1899^{*}$ \\
\hline TBB & $0.1331^{*}$ & $0.2468^{*}$ & $0.1921^{*}$ & $0.1794^{*}$ & $0.2145^{*}$ & $0.3741^{*}$ \\
\hline UNE & 0.1348 & 0.1034 & 0.1937 & 0.1847 & 0.1357 & 0.0577 \\
\hline RAS & -0.2349 & -0.2145 & -0.2623 & -0.1201 & -0.3533 & -0.4897 \\
\hline PD & 0.0192 & 0.0550 & 0.1373 & 0.0407 & 0.0699 & 0.0326 \\
\hline GPD & -0.0175 & -0.0286 & -0.0448 & -0.0929 & -0.1067 & -0.0188 \\
\hline COR & 0.1087 & 0.0605 & 0.0706 & 0.0823 & 0.1226 & $0.1494^{*}$ \\
\hline INF & 0.0624 & 0.1236 & 0.1111 & 0.0922 & 0.1309 & 0.6062 \\
\hline FDI & -0.0019 & -0.0245 & -0.0019 & -0.0060 & -0.0124 & -0.0155 \\
\hline EXP & $-0.0583^{*}$ & $-0.0142^{*}$ & $-0.0422^{*}$ & $-0.0459^{*}$ & $-0.0277^{*}$ & $-0.1246^{*}$ \\
\hline IMP & $-0.0010^{*}$ & -0.0047 & -0.0019 & $-0.0017^{*}$ & $-0.0236^{*}$ & $-0.0024^{*}$ \\
\hline
\end{tabular}


Table 3

Results of the hypothesis verification regarding asymmetry between drivers and tax gaps in terms of countries with different level of shadowing of the economy

\begin{tabular}{|c|c|c|c|c|c|c|}
\hline & ALL & $\mathbf{> 5 0 \%}$ & $\mathbf{4 0 - 5 0 \%}$ & $\mathbf{3 0 - 4 0 \%}$ & $\mathbf{2 0 - 3 0 \%}$ & $<\mathbf{2 0 \%}$ \\
\hline TP & 0.0257 & 0.0305 & 0.0494 & 0.0584 & 0.0430 & 0.0165 \\
\hline TBB & 0.3658 & 0.4025 & 0.4028 & 0.2145 & 0.3057 & 0.3838 \\
\hline UNE & 0.0015 & 0.0014 & 0.0245 & 0.1357 & 0.0187 & 0.0072 \\
\hline RAS & -0.2146 & -0.1851 & -0.2861 & -0.3393 & -0.2186 & -0.2145 \\
\hline PD & 0.3657 & 0.3411 & 0.3606 & 0.2699 & 0.2406 & 0.4935 \\
\hline GPD & -0.0257 & -0.0255 & -0.0242 & -0.0219 & -0.0166 & -0.0882 \\
\hline COR & 0.0987 & 0.0978 & 0.0901 & 0.0126 & 0.0825 & 0.1957 \\
\hline INF & 0.0125 & 0.0192 & 0.0082 & 0.0130 & 0.0243 & 0.1236 \\
\hline FDI & $-0.1456^{*}$ & $-0.1877^{*}$ & $-0.1765^{*}$ & $-0.0124^{*}$ & $-0.0155^{*}$ & $-0.1245^{*}$ \\
\hline EXP & -0.2364 & -0.2401 & -0.1780 & -0.6711 & -0.1246 & -0.5142 \\
\hline IMP & -0.3659 & -0.4338 & -0.4334 & -0.0236 & -0.2254 & -0.1247 \\
\hline
\end{tabular}

framework of the study are not analysed in more detail. Thirdly, the sample size was due to the limited data for some countries. It did not allow to be taken into account for a greater number of factors. Fourthly, the tax policy gap formation factors are not explored predominantly, and their separation with the factors of tax compliance gap formation is not carried out.

Further research may be devoted to the construction of a model that would quantify the loss of the economy due to the tax policy gap and, accordingly, would determine the factors of its origin.

\section{References:}

1. Akinaboade, O. (2014). Regulation, SMEs' Growth and Performance in Cameroon's Central and Littoral Provinces' Manufacturing and Retail Sectors. African Development Review, Vol. 26, Issue 4, 597-609.

2. Annan, B., Bekoe, W., \& Nketiah-Amponsah, E. (2012). Determinants of Tax Evasion in Ghana: 1970-2010. International Journal of Economic Sciences and Applied Research, 6 (3), 97-121.

3. Devos, K. (2014). Factors Influencing Individual Taxpayer Compliance Behaviour. Springer publisher.

4. Hasseldine, H.D. \& Bebbington, J.K. (1991). Blending economic deterrence and fiscal psychology models in the design of responses to tax evasion: the New Zealand experience. Journal of Economic Psychology, Vol. 12 No. 2, 299-324.

5. Langford, B., \& Ohlenburg, T. (2015). Tax revenue potential and effort. International Growth Centre Working Paper.

6. Lewis, A. (1982). The Psychology of Taxation. Martin Robertson, Oxford.

7. Murphy, R. (2019). The European Tax Gap. A report for the Socialists and Democrats Group in the European Parliament. Global Policy.

8. Riahi-Belkaoui, A. (2004). Relationship between tax compliance internationally and selected determinants of tax morale. Journal of International Accounting, Auditing and Taxation, Vol. 13 No. 3, 135-143

9. Stack, S. (2010). General deterrence theory. In F. Cullen and P. Wilcox (Eds), Encyclopedia of Criminological Theory, Sage Publications.

10. VAT Gap Factsheet. (2017). European Commission Director General of Taxation. Retrieved from https://ec.europa.eu/taxation_customs/sites/taxation/files/vat_gap_factsheet_2017.pdf. (date of access 09.09.2019). 